\title{
ボロノイ分割の一般化について 一ネットワークによる空間非一様性の考慮*
}

花原 和之 ${ }^{\dagger}$

\author{
On Generalization of Voronoi Diagram \\ -Consideration on Space Non-uniformity due to Network*
}

Kazuyuki HANAHARA $^{\dagger}$

\begin{abstract}
Voronoi diagram is a typical partitioning of plane according to a number of given points on the plane referred to as generators, based on the Euclidean distances from the points. In the current study, a generalization of such voronoi diagram is discussed from the viewpoint of various consideration on distance. On the basis of discrete voronoi decomposition approach, we take into account the various distance metrics other than the conventional Euclidean distance. The existence of a pathway network to shorten the distance gives the space a non-uniformity in distance. We propose an approach for voronoi decomposition under this non-uniformity. Different weights of generators as well as various evaluations of the distance for the voronoi decomposition are also taken into consideration. A number of calculated examples demonstrate the significance of these various conditions on the obtained voronoi diagrams.
\end{abstract}

\section{1. 緒言}

平面あるいは空間を複数の拠点からの距離にもとづい て分割することが有用である場合がある。その典型的な 例がFig. 4(a) に示すようなボロノイ図 $[1,2]$ であり，与 えられた拠点の各々に対し，それらが最も近くなる点の 集合により平面が領域分割されている。これらの拠点を 母点あるいは生成元 (generator) とよぶ，ボロノイ図は 母点間の垂直二等分線による平面の分割により得られる. ボロノイ図は, その特性から, 様々な施設配置問題に適 用可能である $[3]$. たとえば，公共施設の位置を母点とす るボロノイ図が得られれば, これを参照することにより 利用者は居住地から最も近い施設を知ることができ，施 設の側は担当が想定される領域にもとづいて利用者数を 見積もることなどが可能となる。このような静的な対象 に加え, 移動ロボットやマルチエージェントの動作計画 へのボロノイ図の適用 [4-6]や，人間の集団としてのふ るまいのボロノイ図を用いた解析 [7] も報告されている.

* 原稿受付 2020 年 5 月 1 日

* 第 62 回自動制御連合講演会にて一部を「ボロノイ図の一 般化の試み」として発表 (2019 年 11 月)

†岩手大学 理工学部 Faculty of Science and Engineering, Iwate University; 4-3-5 Ueda, Morioka, Iwate 020-8551, JAPAN

Key Words: voronoi diagram, graph, network, distance functions, computational geometry.
また，ボロノイ図により得られる近接領域を関数近似の サンプル点配置に利用する研究 [8] も報告されるなど, 幅 広い応用事例が存在する.

こういったボロノイ図の考え方をグラフあるいはネッ トワークに適用したものとして，ネットワークボロノイ 図 $[9,10]$ が考えられている. これは, 頂点と, 距離に相 当する重み付きの辺によって構成されるグラフに対し， 母点となる頂点群からのグラフ上の距離により, 他のす べての頂点を分類するものである，たとえば，道路網を 経路として想定した場合の, 最短距離で到達できる施設 群による道路上の各地点の分類がこれに相当する. 道路 が張り巡らされた街中での移動の経済性を考慮した施設 配置 [11] はこのようなネットワークボロノイ図の典型的 な適用事例の一つである.

ボロノイ図あるいはネットワークボロノイ図を拡張あ るいは一般化する研究も行われている。 たとえば, 文 献 [12] では, 線分や面領域を生成元とする場合や，母 点に加法的な重みを考慮する, といった一般化の事例が 示されている. Ederら [13]は，そのような重み付きボ ロノイ図の一般化ならびにその高速計算手法について述 べている. 距離としてユークリッド距離以外を用いた場 合も紹介されている $[12,14]$. 母点を中心とする円ある いは球を想定し，その大きさを考慮するラゲール距離を 用いたボロノイ図の研究 $[15,16]$ も行われており，その 
応用例として果物の表皮パターンの生成 [17] や曲面の テセレーションへの適用 [18] も報告されている。い ゆるチェビシェフ距離のボロノイ図を高速に求めるアル ゴリズムの提案 [19] もなされいる. Boissonatら [20]や Kwokら [21] は曲面上のボロノイ図を扱っており, これ も通常とは異なる距離を扱ったものと考えることもでき る. また, 複数の母点を考慮する高階ボロノイ図 [14]や 周遊距離ボロノイ図 [22]についても研究が報告されてい る. 一般次元のボロノイ図の研究も行われている. Suri ら [23] は，母点に存在確率が付随する場合のボロノイ分 割について報告している。ネットワークボロノイ図にお いても, 線や面に相当する複数の頂点を同一の生成元と するような拡張が報告されている $[24]$.

ボロノイ図の考え方による領域分割は，様々な場面に おいて極めて有効な手法である。しかしながら，実際の 問題においては，非ユークリッド的な距離，重要度が均 等でない母点 (拠点), 距離の非線形な効用といった様々 な要因の考慮を必要とする場合がある。それらに加え， ネットワーク等の存在による限定された距離短縮効果の 考慮が必要となる場合もある。本論文では，母点からの 実効的な距離による領域分割という観点からボロノイ分 割を考える。すなわち，離散ボロノイ分割に重み付きグ ラフを組み合わせて拡張することにより，部分的な距離 短縮効果, 非線形距離評価, 母点の重み等を統合して勘 案することを可能とする, ボロノイ図の一般化を示す.

いくつかの計算例により, 本論文で示したボロノイ分 割の一般化の意義を検討する.

\section{2. 離散ボロノイ分割}

任意の 2 点間の距離が場所によらず同一の距離関数に よって与えられる, 一様な空間を考える。ユークリッド 距離を想定し，すべての母点が対等な重みを持つ場合， そのボロノイ分割は，平面であれば母点間の垂直二等分 線，空間であれば母点間の垂直二等分面によって行うこ とができる。このような場合には，これらの交点，交線 を求める幾何学的な計算によってボロノイ図を求めるこ とは困難ではない，しかしながら，非ユークリッド的な 距離関数を想定し，それらの距離が場所の影響を受ける 非一様な空間を対象とし, 非線形な距離評価をも考慮し, 各母点に異なる重みを想定する, といった一般の場合, そのような幾何学的な手法での計算の実装は困難である. 本研究では, 対象となる空間領域の要素分割にもとづく, 次のような離散ボロノイ分割の手法を用いる。

$D$ 次元空間 $\mathcal{R}^{D}$ における対象領域を $N_{E}$ 個の適当な要 素に分割し, 各々の要素 $m \in\left\{1, \cdots N_{E}\right\}$ に対し, 代表位 置座標 $\boldsymbol{x}_{m}$ を定める。ここでの要素分割は有限要素法の メッシュ分割のようなものを想定しているが，対象領域 を重複することなく被覆するものであれば，目的に応じ た様々な要素分割が考えられる。 また, 代表位置座標と して要素内の任意の位置を選択することができるが，6
章における本論文の計算例で用いた分割では, 要素の重 心位置としている。

$N_{G}$ 個の母点 $\boldsymbol{p}_{n}\left(n=1, \cdots, N_{G}\right)$ に対し, これらの要 素の分類を

$$
g_{m}=\underset{n \in\left\{1, \cdots N_{G}\right\}}{\arg \min } d\left(\boldsymbol{p}_{n}, \boldsymbol{x}_{m}\right)
$$

と表す ${ }^{1}$. ここで, $d$ は母点 $\boldsymbol{p}_{n}$ と要素代表位置 $\boldsymbol{x}_{m}$ の距 離を表す。(1) 式により得られる $g_{m} \in\left\{1, \cdots, N_{G}\right\}$ は, 距 離関数 $d$ の意味で要素 $m$ に最も近い母点を表す。これに より, 母点 $n$ のボロノイ領域が要素集合 $\left\{m \mid g_{m}=n\right\}$ として得られる。距離関数 $d$ は, たとえばもっとも一般 的なユークリッド距離の場合，次式のようになる.

$$
d_{E}\left(\boldsymbol{p}_{n}, \boldsymbol{x}_{m}\right)=\left[\left(\boldsymbol{p}_{n}-\boldsymbol{x}_{m}\right)^{T}\left(\boldsymbol{p}_{n}-\boldsymbol{x}_{m}\right)\right]^{(1 / 2)}
$$

このような離散的なアプローチにおいても，要素分割 を細かくすることにより，十分な精度のボロノイ分割を 得ることができる。 また, 応用の観点からは, ある程度 の有限の大きさに区分された要素で構成されるボロノイ 図のほうが作業管理等において有用である場合も考えら れる。

空間の要素分割に関しては, 計算手順の実装の観点か らは正方形要素や立方体要素が容易である。しかしなが ら, このアプローチは単純に要素の代表位置による分類 を行っているのみであり, 任意の要素分割に対して直ち に適用可能である.

\section{3. ネットワークの存在による空間の非一 様性を考慮した離散ボロノイ分割}

一様な空間においては, (2) 式のユークリッド距離に 示すように，2 点間の距離は場所によらず同一の距離関 数によって与えられる (幾何学的距離). しかしながら, 特に実際的な観点からは, 実質的な距離が場所によって 異なる状況が考えられる。たとえば，車両の移動に関す る所要時間で距離を測る場合, 速度が低下する未整地の 区域や速度が向上する高速道路の存在により，2 点間の 実質的距離（実効距離）はそれらの未整地区域や高速道 路出入口との位置関係に依存する. すなわち, 距離関数 が場所によって異なる非一様な空間となる. 本研究では, 空間内に実効距離を短縮するネットワークが存在する場 合を取り扱う。

なお，本論文ではネットワークが連結であることを仮 定している. 非連結なネットワークを扱う場合であって も, それらのネットワークの適切な一部の頂点間に相互 の幾何学的距離に対応する仮想的な経路を設定し，ネッ トワークを統合することにより，同様に取り扱うことが 可能となる.

\footnotetext{
距離は実数值であり, $\arg \min$ は該当する単一の母点 を与えるものとしている. 本論文の他の部分でも同様 である。
} 


\section{1 実効距離行列}

そのようなネットワークを重み付きグラフとして定式 化する，空間内に，位置を $\boldsymbol{v}_{1}, \cdots, \boldsymbol{v}_{N_{V}}$ とする $N_{V}$ 個の 頂点が配置され，それらの頂点間に空間の幾何学的距離 よりも短い距離に相当する重みをもつ辺が存在する重み

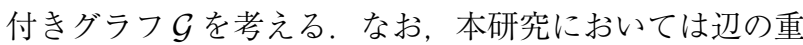
みすなわちグラフの辺の長さは正のみとしている.グラ

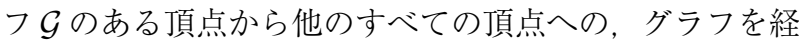
由する場合の最短距離は Dijkstra 法 [25]によって容易に 求めることができる。グラフ $\mathcal{G}$ の頂点間の実効距離は, このようにして得られた最短距離となる。グラフ $\mathcal{G} の$ 実効距離行列を $\boldsymbol{D}=\left[d_{i j}\right]\left(i, j=1, \cdots, N_{V}\right)$ と表す。ここ

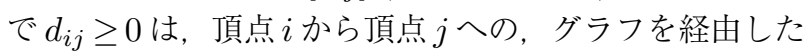
最短距離である。本論文では，空間内にこのようなグラ ᄀ $\mathcal{G}=\left(\left\{\boldsymbol{v}_{1}, \cdots, \boldsymbol{v}_{N_{V}}\right\}, \boldsymbol{D}\right)$ が配置されている場合を取り 扱方。

\section{2 母点からの実効距離によるグラフ頂点の分類}

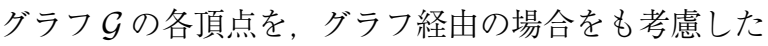
母点からの実効距離によって分類する。ここで，母点 $n$ からグラフ頂点 $j$ への実効距離 $\hat{d}_{n j}\left(n=1, \cdots, N_{G}, j=\right.$ $\left.1, \cdots, N_{V}\right)$ は

$$
\hat{d}_{n j}=\min _{i}\left(d\left(\boldsymbol{p}_{n}, \boldsymbol{v}_{i}\right)+d_{i j}\right)
$$

として得られる。 この実効距離にもとづく，グラフ頂点 $j$ の属する母点 $\hat{g}_{j}$ 抢よびその頂点に対する母点からの実 効距離 $\hat{d}_{j}$ は, 次式により定まる。

$$
\begin{aligned}
& \hat{g}_{j}=\underset{n \in\left\{1, \cdots N_{G}\right\}}{\arg \min } \hat{d}_{n j} \\
& \hat{d}_{j}=\hat{d}_{\hat{g}_{j} j}
\end{aligned}
$$

なお，グラフ頂点が幾何学的距離で最も近い母点に分 類されるとは限らない.すなわち, 幾何学的距離では遠 方でも，グラフを経由した実効距離ではより近い，別の 母点に分類される場合がある.

\section{3 母点からの実効距離による領域分割}

3.2 節の手順により各母点に分類されたグラフ頂点は, 対応する母点の代理としての意味を持つ。したがって， これらの頂点を元々の母点に追加して得られる拡大母点 群にもとづいて空間の離散ボロノイ分割を行い，得られ た各領域を元々の母点にしたがって分類することにより， ネットワークの影響を考慮した領域分割を達成する。こ の場合の手順は基本的には (1) 式と同様であるが, 代理 母点であるグラフ頂点 $j$ の場合, 要素代表位置への距離 は $\hat{d}_{j}+d\left(\boldsymbol{v}_{j}, \boldsymbol{x}_{m}\right)$ として対応する母点から頂点 $j$ までの 実効距離 $\hat{d}_{j}$ を補正項として加えたものを用いる.

この拡大母点群の導入により，2 点間の実効距離がネッ トワークの影響を受ける非一様な空間の場合であっても, 以下に述べる距離評価や母点の重みをも含めて統一的に 取り扱うことが可能となる.

\section{4. 距離評価と母点の重みの考慮}

ボロノイ図の実際的な用途に㧍いては, 空間の幾何学 的な距離あるいは前節のようにして得られた実効距離に 対し, 非線形の距離評価を適用して領域分割を行うほう が都合が良い場合が考えられる。また，母点からの距離 の評価に個々の母点の重要度あるいは重みを何らかの形 で考慮するほうが適切な場合が存在する。これらを考慮 したボロノイ分割について考える。

\section{1 距離評価}

距離の影響あるいは効用について非線形の評価を行う. すなわち, ボロノイ分割に際し, 通常の母点 $\boldsymbol{p}_{n}$ に対し ては, 要素代表位置 $\boldsymbol{x}_{m}$ との幾何学的距離 $d=d\left(\boldsymbol{p}_{n}, \boldsymbol{x}_{m}\right)$ を $e(d)$ として評価する。 また, グラフ頂点である代理 母点 $\boldsymbol{v}_{j}$ に対しては, 幾何学的距離に加えて対応する母 点への実効距離 $\hat{d}_{j}$ を考慮した $\hat{d}=\hat{d}_{j}+d\left(\boldsymbol{v}_{j}, \boldsymbol{x}_{m}\right)$ を $e(\hat{d})$ として評価する。評価関数 $e$ は単調増加であれば任意の ものが適用可能であるが, 一例として, 本研究では以下 の 3 種類を取り扱う。

\subsection{1 直接評価}

幾何学的距離あるいは実効距離を直接評価する.

$$
e_{I}(d)=d
$$

\subsection{2 平方評価}

距離の影響をその平方で評価する。

$$
e_{S}(d)=d^{2}
$$

たとえば，空間のユークリッド距離をその平方で評価す る場合, 距離による減衰の効果が二乗となる, 重力や電 磁力の影響に類似したボロノイ分割となる。

\subsection{3 平方根評価}

距離の影響をその平方根で評価する。

$$
e_{R}(d)=\sqrt{d}
$$

この場合，母点から遠方であるほど，直接評価の場合に 比べて距離の影響が小さくなり, 母点の重みが大きく反 映されるボロノイ分割となる.

ただし， $e\left(d_{1}\right)=e\left(d_{2}\right)$ であれば当然 $d_{1}=d_{2}$ であり， すべての母点の重みが同等である場合，いずれの距離評 価を用いても同一のボロノイ分割が達成されることとな る。すなわち，これらの距離評価の影響は，次節に示す 母点の重みと密接に関連している.

\section{2 母点の重みの考慮}

すべての母点を同等に扱うべきでない場合のボロノイ 分割に際し，母点 $n$ の重み $w_{n}$ を導入する。 母点加要 素代表位置への距離 $d$ の評価 $e(d)$ にこの重みを勘案し, 重みに反比例するものとしてボロノイ分割のための距離 を評価する．すなわち， $e(d) / w_{n}$ が最小となる母点 $n$ に その要素を分類する。 
5. ネットワークによる実効距離, 距離評 価，母点の重みを考慮したボロノイ分割

ここまでで述べた，ネットワークの存在による空間の 非一様性，非線形の距離評価㧍よび母点の重みの影響を 考慮した離散ボロノイ分割の手順を整理しておく。

$N_{G}$ 個の母点に $N_{V}$ 個のグラフ頂点を加えた, 次式 に示す拡大母点群 $\boldsymbol{p}_{1}^{*}, \cdots, \boldsymbol{p}_{N_{G}^{*}}^{*}\left(N_{G}^{*}=N_{G}+N_{V}\right)$ を導入 する。

$$
\boldsymbol{p}_{k}^{*}= \begin{cases}\boldsymbol{p}_{k} & \left(k=1, \cdots, N_{G}\right) \\ \boldsymbol{v}_{j} & \left(k=N_{G}+1, \cdots, N_{G}^{*}, j=k-N_{G}\right)\end{cases}
$$

距離評価と母点の重みを考慮し，(4) 式を修正した次式 により，各グラフ頂点の属する母点を定める.

$$
\hat{g}_{j}=\underset{n \in\left\{1, \cdots N_{G}\right\}}{\arg \min } e\left(\hat{d}_{n j}\right) / w_{n} \quad\left(j=1, \cdots, N_{V}\right)
$$

これより，拡大母点の重みが次のように定められる。

$$
w_{k}^{*}= \begin{cases}w_{k} & \left(k=1, \cdots, N_{G}\right) \\ w_{\hat{g}_{j}} & \left(k=N_{G}+1, \cdots, N_{G}^{*}, j=k-N_{G}\right)\end{cases}
$$

拡大母点 $\boldsymbol{p}_{k}^{*}\left(k=1, \cdots, N_{G}^{*}\right)$ と要素代表位置 $\boldsymbol{x}_{m}(m=$ $\left.1, \cdots, N_{E}\right)$ の間の実効距離は

$$
\begin{aligned}
& \hat{d}\left(\boldsymbol{p}_{k}^{*}, \boldsymbol{x}_{m}\right)= \\
& \begin{cases}d\left(\boldsymbol{p}_{k}, \boldsymbol{x}_{m}\right) & \left(k=1, \cdots, N_{G}\right) \\
\hat{d}_{j}+d\left(\boldsymbol{v}_{j}, \boldsymbol{x}_{m}\right) & \left(\begin{array}{l}
k=N_{G}+1, \cdots, N_{G}^{*}, \\
\left.j=k-N_{G}\right)
\end{array}\right.\end{cases}
\end{aligned}
$$

となり, グラフ頂点の場合には，その対応する母点から の実効距離の補正項を加えたものとなる.

距離評価と母点の重みを考慮した， $N_{G}^{*}$ 個の拡大母点 群に対する離散ボロノイ分割は

$$
g_{m}^{*}=\underset{k \in\left\{1, \cdots, N_{G}^{*}\right\}}{\arg \min } e\left(\hat{d}\left(\boldsymbol{p}_{k}^{*}, \boldsymbol{x}_{m}\right)\right) / w_{k}^{*}
$$

により行われる，拡大母点群に含まれる，グラフ頂点に よる代理母点を考慮すれば，(10) 式の結果を参照し，

$$
g_{m}=\left\{\begin{array}{cc}
g_{m}^{*} & \left(g_{m}^{*} \in\left\{1, \cdots, N_{G}\right\}\right) \\
\hat{g}_{j} & \left(g_{m}^{*} \in\left\{N_{G}+1, \cdots, N_{G}^{*}\right\},\right. \\
& \left.j=g_{m}^{*}-N_{G}\right)
\end{array}\right.
$$

として, 各要素が元々の母点 $g_{m} \in\left\{1, \cdots, N_{G}\right\}$ に分類さ れる。

\section{6. 興味深いいくつかの計算例}

本論文で考察した，ネットワークの存在による空間の 非一様性と距離評価の影響を，いくつかの代表的な距離 の場合について示す，また，母点の重みをも考慮したボ ロノイ分割の計算例を示す.

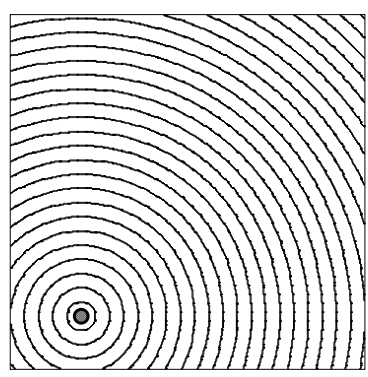

(a) Plain

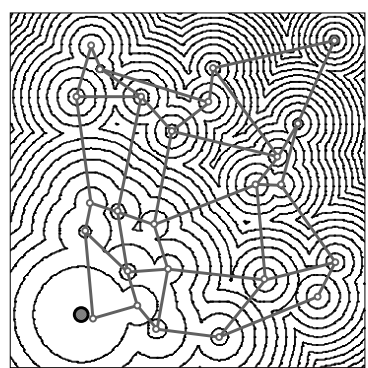

(c) Square

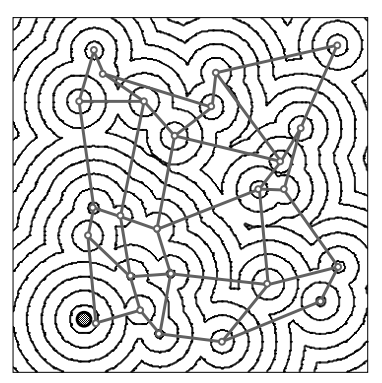

(b) With network

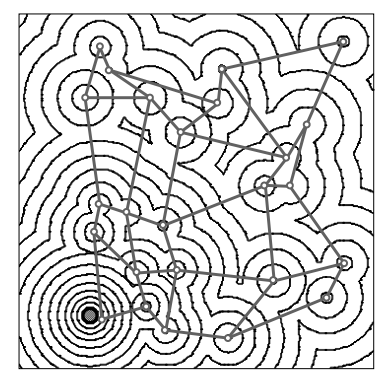

(d) Squareroot
Fig. 1 Distance demonstration: Euclidean

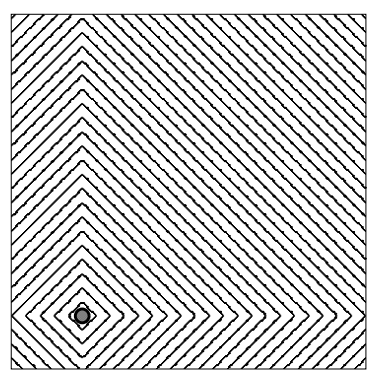

(a) Plain

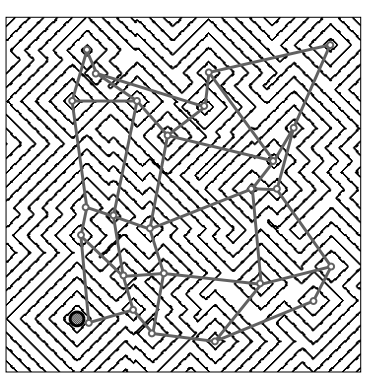

(b) With network
Fig. 2 Distance demonstration: Manhattan

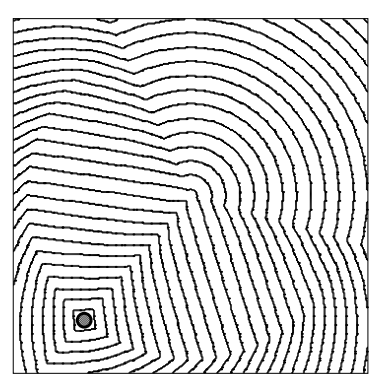

(a) Plain

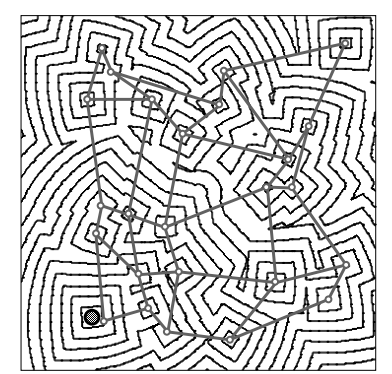

(b) With network
Fig. 3 Distance demonstration: Karlsruhe

\section{1 ネットワーク下の距離と距離評価}

本研究では，(2) 式に示したユークリッド距離に加え， 以下の 2 種類の距離 $[12]$ を用いる.

移動が直交座標系の座標軸方向に制限されるマンハッ タン距離

$$
d_{M}\left(\boldsymbol{p}_{n}, \boldsymbol{x}_{m}\right)=\sum_{i}\left|p_{n i}-x_{m i}\right|
$$

は，格子状の街路における距離を表すものとして広く用 いられている。ここで, $p_{n i}, x_{m i}$ は母点位置 $\boldsymbol{p}_{n}$ および 


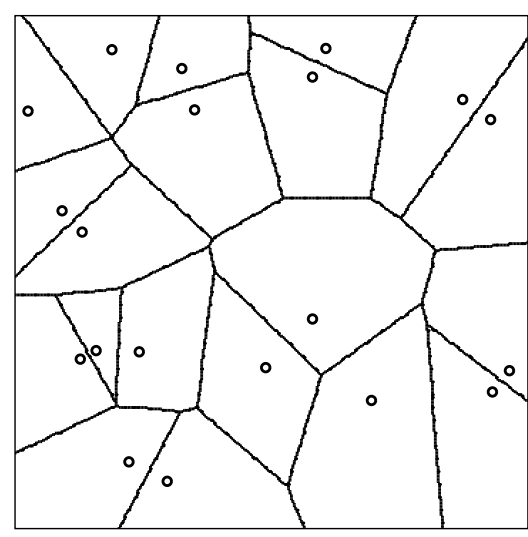

(a) Euclidean

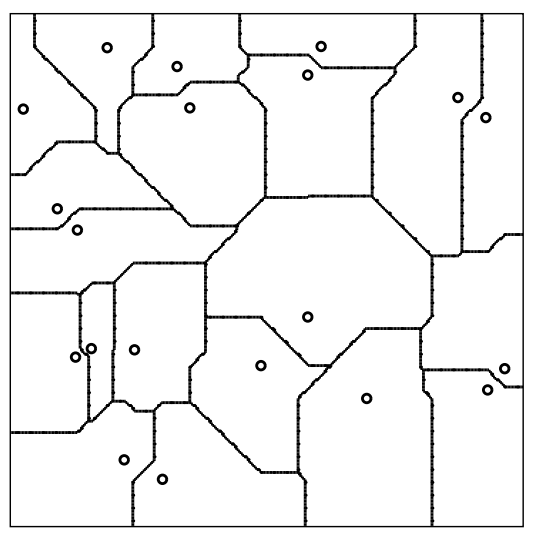

(b) Manhattan

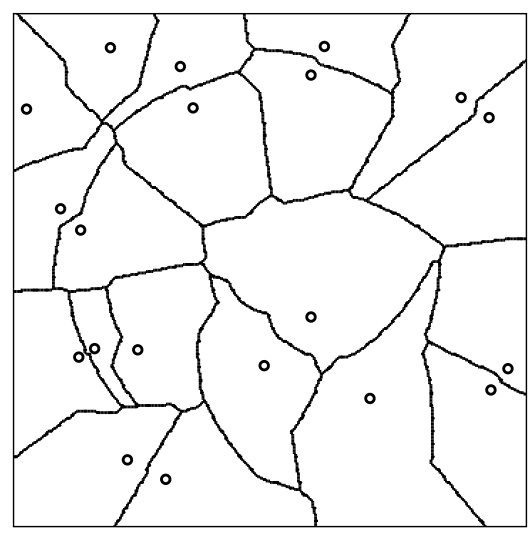

(c) Karlsruhe

Fig. 4 Voronoi diagram based on various distances

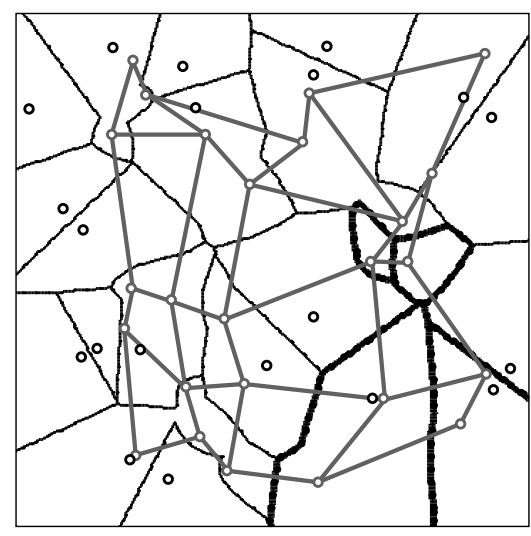

(a) With network

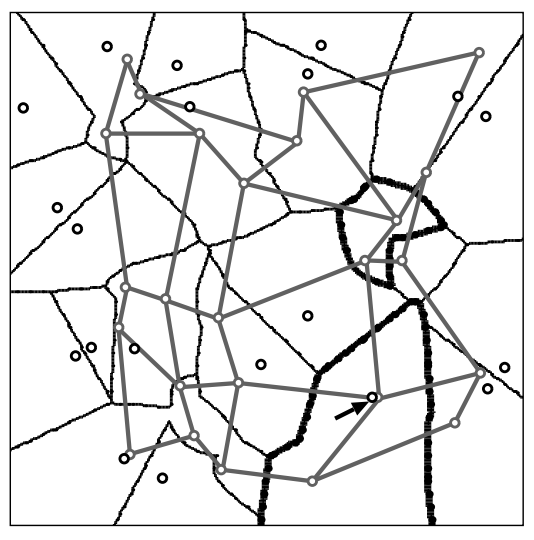

(b) One generator displaced

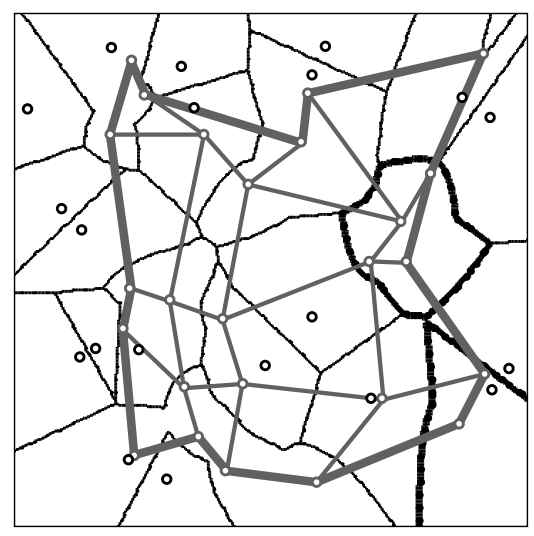

(c) Enhanced circuit network

Fig. 5 Voronoi diagram with network based on Euclidean distance

要素代表位置 $\boldsymbol{x}_{m}$ の座標軸 $i$ の值を表す.

移動が中心点からの放射方向と周方向に制限される カールスルーエ距離は，空間に設定された放射中心 $\boldsymbol{o}$ と $\boldsymbol{p}_{n}$ および $\boldsymbol{x}_{m}$ の放射方向距離

$$
r_{p}=\left\|\boldsymbol{p}_{n}-\boldsymbol{o}\right\|, \quad r_{x}=\left\|\boldsymbol{x}_{m}-\boldsymbol{o}\right\|
$$

およびそれらの放射方向べクトルのなす角

$$
\theta=\cos ^{-1}\left(\frac{\left(\boldsymbol{p}_{n}-\boldsymbol{o}\right)^{T}\left(\boldsymbol{x}_{m}-\boldsymbol{o}\right)}{r_{p} r_{x}}\right)
$$

を用いて

$$
d_{K}\left(\boldsymbol{p}_{n}, \boldsymbol{x}_{m} ; \boldsymbol{o}\right)=\min \left\{\begin{array}{l}
r_{p}+r_{x} \\
r_{p} \theta+\left|r_{p}-r_{x}\right| \\
r_{x} \theta+\left|r_{p}-r_{x}\right|
\end{array}\right.
$$

と表される。(16) 式は, 中心を通過する放射方向のみ の移動, $\boldsymbol{p}_{n}$ が存在する周上と放射方向の移動, $\boldsymbol{x}_{n}$ が存 在する周上と放射方向の移動のうち, 距離が最短となる ものによって $\boldsymbol{p}_{n}$ から $\boldsymbol{x}_{m}$ の距離を定めることを示して いる.

Figs. 1 3に, 2 次元平面の場合の単一母点からの距離 評価の分布の例を示す.
Fig. 1 はユークリッド距離の場合であり，Fig. 1(a)に 示すように，一様な空間では同心円状の拡がりとなる. Fig. 1(b) は空間のユークリッド距離を $1 / 3$ に短縮する ネットワークが存在する場合である。ネットワークの 存在により，特にネットワーク頂点への距離の短縮が顕 著となっていることがわかる. Fig. 1(c) および (d) は, Fig. 1(b)における距離評価を平方および平方根とした場 合である. Fig. 1(c)の平方距離評価の場合, ネットワー クによる距離短縮の効果が母点から遠方となるほど顕著 となっており, 逆にFig. 1(d)の平方根距離評価の場合に は，遠方における距離短縮の効果がやや低減している. また，母点ならびにネットワーク頂点からの距離評価の 分布が同心円状に徐々に密あるいは徐々に疎となってい ることが確認できる。

Fig. 2 およびFig. 3 はそれぞれマンハッタン距離およ びカールスルーエ距離の場合を示す。ここで適用されて いるネットワークはFig. 1のものと同一であり，空間の ユークリッド距離を $1 / 3$ に短縮するものとなっている. Fig. 2(a) およびFig. 3(a) はそれぞれの距離の分布の特 徵をよく表している.Fig. 2(b) およびFig. 3(b)には, Fig. 1(b) の場合と同様にネットワークによる距離の短縮 が示されているが，それぞれの距離の特徵的なパターン 


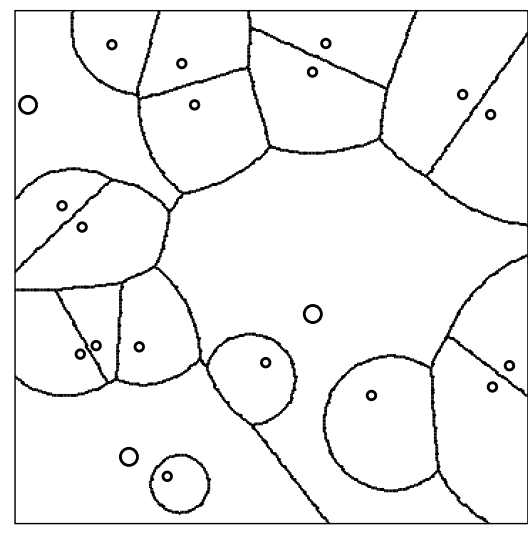

(a) Immediate evaluation

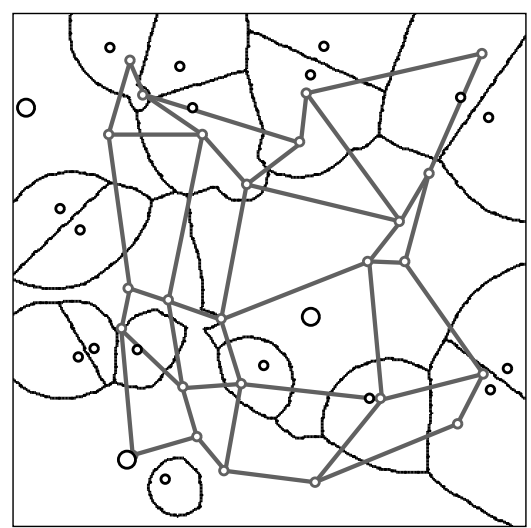

(d) Immediate with network

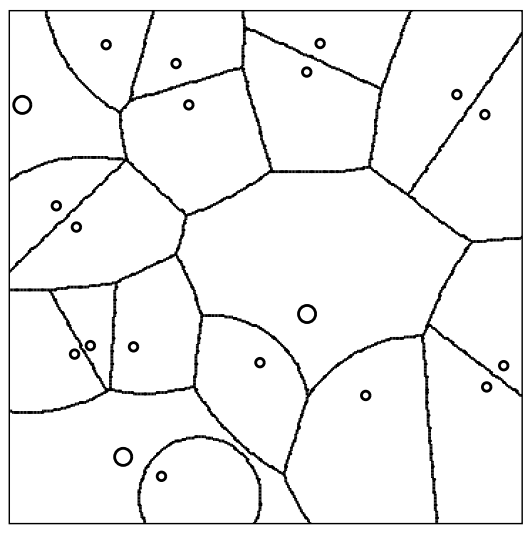

(b) Square evaluation

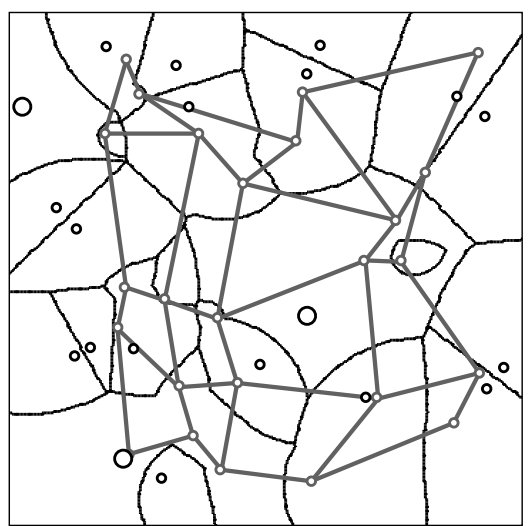

(e) Square with network

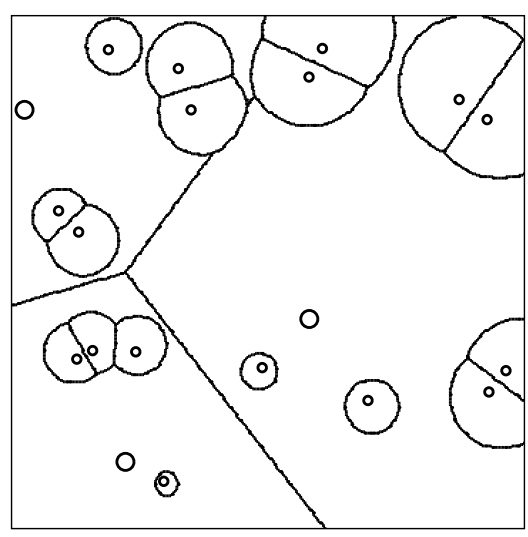

(c) Squareroot evaluation

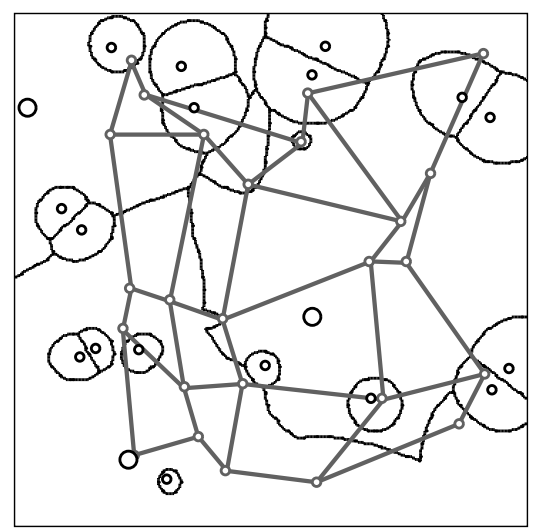

(f) Squareroot with network

Fig. 6 Voronoi diagram of weighted generators based on various distance evaluations

を確認することができる．

\section{2 様々な条件下でのボロノイ分割の計算例}

正方形領域の $400 \times 400$ の離散要素にもとづくボロノ イ分割の計算例を示す.

標準的なボロノイ図の例を Fig. 4(a)に示す。また，以 下の計算例では基本的にこれと同一の母点配置を用いて いる. マンハッタン距離, カールスルーエ距離にもとづ くボロノイ分割を Fig. 4(b), (c) に示す. 同一の母点配置 であっても，特に領域の形状が大きく異なることが確認 できる。

頂点間距離をユークリッド距離の $1 / 3$ とするネット ワークによる空間の非一様性を導入した場合のボロノイ 分割を Fig. 5(a) に示す. Fig. 4(a) と比較すれば，特に ネットワーク頂点の比較的近傍の母点がその領域を拡げ ていることが確認できる，また，この場合には，図中の 太線で囲まれた部分のように，飛び地となる領域を持つ 母点が存在する可能性がある。やや右下に配置されてい るネットワーク頂点近傍の母点をわずかに右に配置した 場合のボロノイ分割を Fig. 5(b) に示す. 移動した母点を 図中に矢印で示す。この図において太線で示されている 領域が当該母点のものである。この場合，この母点が新 たなネットワーク頂点を獲得したことにより, 飛び地と なっていた領域が有意に拡大していることがわかる。一 般に，幾何学的距離のみにもとづくボロノイ分割では，
母点の微小な移動が全体の結果に及ぼす影響は限定的で ある. しかしながらこの例のようにネットワークの存在 を考慮する場合には，母点のわずかな位置の違いが，ボ ロノイ分割の結果に大きな差異をもたらす可能性があ ることを示している. Fig. 5(c) はネットワークの外周部 の頂点間距離を $1 / 6$ とした場合のボロノイ分割である. 典型的な部分は太線で囲まれた領域であるが，Fig. 5(a) と比較すれば, 外周部の頂点近傍の母点の領域がネット ワークの外周部を通じて拡大していることが確認できる.

Fig. 6 に, 左上, 左下, 中央部の 3 つの母点の重みを 2 倍にした場合のボロノイ分割を示す. Fig. 6(a)の直 接距離評価の場合と比較すれば，(b)の平方距離評価の 場合には遠方における母点の重みの影響が小さくなっ ており, (c)の平方根距離評価の場合には母点の重みの 影響が特に遠方でより顕著となっていることがわかる. Fig. 6(d)-(f) は, これらに対応する, 距離を $1 / 3$ に短縮 するネットワークが存在する場合の結果である。特に Fig.6(f) においては，ネットワーク頂点の近隣に位置す る, 2 倍の重みをもつ左下の母点の領域が著しく拡大し ていることが確認できる.

\section{3 計算量について}

本研究では, 単純な離散ボロノイ分割による計算を 行っている，ネットワークを考慮する場合, Dijkstra法 による計算等が必要となるが，これらはいわゆる前処理 
に相当するため, 大きな計算量は必要としない. したがっ て, 距離の計算量を $C_{D}$ とするとき, 計算量は実質的に $O\left(C_{D} N_{E}\left(N_{G}+N_{V}\right)\right)$ となる，本研究では C 言語で作成 したプログラムによる実装を行っているが, ここで示し た 16 万要素 $(400 \times 400), 20$ 母点, 25 グラフ頂点の計 算例では, 最も時間を要するカールスルーエ距離による ボロノイ分割の場合でもやや旧式のワークステーション (Dell Precision (インテル Xeon, 2.33GHz，4GBメモ リ))で数秒程度であった。 また，これらの計算は本質的 に要素単位での処理が可能であり，大規模な問題を扱う 場合, 並列処理をはじめとした様々な効率的な計算手法 の適用も可能であると考えている。

\section{7. 結言}

本論文では，離散ボロノイ分割の手法を用い，様々な 条件下でのボロノイ分割について議論した。特に，距離 を短縮するネットワークの存在による空間の非一様性を 考慮した離散ボロノイ分割の手法を示した。 また，様々 な距離関数や母点の重みの考慮に加え, それらと独立し た距離評価の導入についても検討した。複数の種類の距 離関数, ネットワークの存在, 母点の重みならびに異な る距離評価のもとでのボロノイ分割の計算例を示し，そ れらの条件の特徵を議論した。なお，計算例では図示お よび計算量の都合から 2 次元の場合に限定したが，提示 した式は, 距離関数も含め, より高次元の場合にも直ち に適用可能である，計算例からは，実効距離を短縮する ネットワークの存在により, 母点位置のわずかな差異が, 結果として得られるボロノイ分割に大きく影響する場合 があることが確認できた。これらを考慮したネットワー ク設計や母点配置についても検討を行っていきたいと考 えている.

\section{参 考文 献}

[1] ドバーグほか (浅野訳): コンピュータ・ジオメトリ, 第 7 章, 近代科学社 (2000)

[2] 杉原: なわばりの数理モデル, 第 1 章, 共立出版 (2009)

[3] 岡部, 鈴木: 最適配置の数理, 朝倉書店 (1992)

[4] J. Cortés, S. M. Martínsz, T. Karatas and F. Bullo: Coverage control for mobile sensing networks; IEEE Transactions on Robotics and Automation, Vol. 20, No. 2, pp. 243-255 (2004)

[5] N. Hayashi, K. Segawa and S. Takai: 2D Voronoi coverage control with Gaussian density functions by line integration; SICE Journal of Control, Measurement, and System Integration, Vol. 10, No. 2, pp. 110-116 (2017)

[6] 中川, 権, 本仲, 三好: ボロノイ分割を用いた複数のク ワッドロータの相互衝突回避に関する数值的検証; 計測 自動制御学会論文集, Vol. 56, No. 1, pp. 31-36 (2020)

[7] J. C. S. Jacques Jr, A. Braun, J. Soldera, S. R. Musse and C. R. Jung: Understanding people motion in video sequences using Voronoi diagrams: Detecting and classifying groups; Pattern Analysis and Applications, Vol. 10, Issue 4, pp. 321-332 (2007)

[8] 廣川, 藤田: ボロノイ図による累積関数近似と適応的大 域最適化; 日本機械学会論文集 (C 編), Vol. 72, No. 718, pp. 1759-1768 (2006)

[9] M. Erwig: The graph Voronoi diagram with applications; Networks, Vol. 36, No. 3, pp. 156-163 (2000)

[10] 蒲原, 上島: ネットワークボロノイ図を用いたグラフ分 割木の提案と最短経路検索への適用; 日本データベース 学会論文誌, Vol. 7, No. 1, pp. 193-198 (2008)

[11] 大場: 最短経路距離による施設の新設や移転が住民にも たらす便益の評価法; 日本都市計画学会 都市計画論文 集, No. 45-3, pp. 133-138 (2010)

[12] 文献 [3] の 2.4 節

[13] G. Eder and M. Held: Weighted Voronoi diagrams in the maximum norm; International Journal of Computational Geometry \&S Applications, Vol. 29, No. 3, pp. 239-250 (2019)

[14] 文献 [2] の 8 章

[15] H. Imai, M. Iri and K. Murota: Voronoi diagram in the Laguerre geometry and its applications; SIAM Journal on Computing, Vol. 14, No. 1, pp. 93-105 (1985)

[16] K. Sugihara: Laguerre Voronoi diagram on the sphere; Journal for Geometry and Graphics, Vol. 6, No. 1, pp. 69-81 (2002)

[17] S. Chaidee and K. Sugihara: Approximation of fruit skin patterns using spherical Voronoi diagrams; Pattern Analysis and Applications, Vol. 20, Issue 3, pp. 783-795 (2017)

[18] S. Chaidee and K. Sugihara: Laguerre Voronoi diagram as a model for generating the tessellation patterns on the sphere; Graphs and Combinatorics, Vol. 36, Issue 2, pp. 371-385 (2020)

[19] E. Papadopoulou and J. Xu: The $L_{\infty}$ Hausdorff Voronoi diagram revisited; International Journal of Computational Geometry \& Applications, Vol. 25, No. 2, pp. 123-141 (2015)

[20] J.-D. Boissonnat, C. Wormser and M. Yvinec: Curved Voronoi diagrams; Effective Computational Geometry for Curves and Surfaces, Springer, pp. 67$116(2007)$

[21] T-H. Kwok, Y. Zhang and C. C. L. Wang: Constructing common base domain by cues from Voronoi diagram; Graphical Models, Vol. 74, pp. 152-163 (2012)

[22] 大山, 鈴木: 周遊距離 Voronoi 図とそれを用いた商業立 地分析; 日本応用数理学会論文誌, Vol. 11, No. 2, pp. 1-14 (2001)

[23] S. Suri and K. Verbeek: On the most likely Voronoi diagram and nearest neighbor searching; International Journal of Computational Geometry \& Applications, Vol. 26, No. 3/4, pp. 151-166 (2016)

[24] 佐藤, 岡部: 線および面を生成元とするネットワークボ ロノイ図を用いた解析ツールの開発; GIS-理論と応用, 
Vol. 14, No. 2, pp. 53-62 (2006)

[25] たとえば, クライツィグ (田村訳): 最適化とグラフ理論, 2.3 節, 培風館 (2003)

\section{著 者略歴}

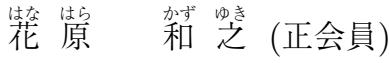

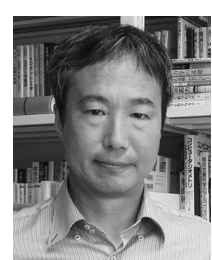

1964 年 12 月 28 日生, 1993 年 3 月大阪 大学大学院基礎工学研究科博士後期課程 修了。同年 4 月大阪府立大学工学部助手, 1996 年 10 月神戸大学工学部講師, 2000 年 4 月同助教授, 2016 年 7 月岩手大学理工学 部教授となり現在に至る。多自由度メカニ ズム, 最適設計, システム工学などの研究に従事, 博士（工 学). 日本機械学会, 日本航空宇宙学会, 米航空宇宙学会, 日 本ロボット学会の会員. 